\title{
Preparation of $\mathrm{Ce}_{0.8} \mathrm{Gd}_{0.2} \mathrm{O}_{1.9}$ Powder Using $\mathrm{CeO}_{2}$ Powder and Gd Precipitation and Effect of $\mathrm{CoO}$ doping on Sintering
}

\author{
Soo-Man $\operatorname{Sim}^{\dagger}$ \\ School of Materials Science and Engineering, Hongik University, Sejong 30016, Korea
}

(Received August 10, 2015; Revised October 1, 2015; Accepted October 4, 2015)

\begin{abstract}
$\mathrm{Ce}_{0.8} \mathrm{Gd}_{0.2} \mathrm{O}_{1.9}\left(\right.$ GDC20) powder was prepared from a mixture of submicron-sized $\mathrm{CeO}_{2}$ powder and Gd precipitates using ammonium carbonate $\left(\left(\mathrm{NH}_{4}\right)_{2} \mathrm{CO}_{3}\right)$ as a precipitant. The mixture was calcined at $700^{\circ} \mathrm{C}$ for $4 \mathrm{~h}$ followed by ball-milling that resulted in the GDC powder with an average particle size of $0.46 \mu \mathrm{m}$. The powder had a very uniform particle size distribution with particle sizes ranging from $0.3 \mu \mathrm{m}$ to $1 \mu \mathrm{m}$. Sintering of undoped GDC samples did not show a relative density of $99.2 \%$ until the temperature was increased to $1500^{\circ} \mathrm{C}$, whereas GDC samples doped with $5 \mathrm{~mol} \% \mathrm{CoO}$ exhibited a significant densification at lower temperature reaching a relative density of $97.6 \%$ at $1100^{\circ} \mathrm{C}$ and of $98.8 \%$ at $1200^{\circ} \mathrm{C}$.
\end{abstract}

Key words : $\mathrm{SOFC}$ electrolyte, GDC, $\mathrm{CeO}_{2}$ powder, $\mathrm{CoO}$ doping, Sintering

\section{Introduction}

G d-doped $\mathrm{CeO}_{2}(\mathrm{GDC})$ has received much attention as an intermediate-temperature solid oxide fuel cell electrolyte due to its higher ionic conductivity than that of YSZ. However, the synthesis of GDC by using Ce and Gd oxide powders requires sintering at high temperatures $\left(>1500^{\circ} \mathrm{C}\right)$ for a long time since densification is very difficult. ${ }^{1)}$ Therefore, powder synthesis methods such as oxalate coprecipitation method, ${ }^{2,3)}$ hydrate precipitation method, ${ }^{4)}$ ammonium carbonate coprecipitation method, ${ }^{5-7)}$ citrate method, ${ }^{8)}$ glycine-nitrate method, ${ }^{9)}$ etc. have been employed to prepare a dense GDC at a low temperatures. Metal carbonate precipitates obtained from ammonium carbonate coprecipitation method undergo less agglomeration during the drying process than that derived from hydrate method. So the ammonium carbonate precipitation method allows us to minimize particle agglomeration in the calcined powders. Also, the precipitates have the advantages of excellent sinterability in that they have a relatively low decomposition temperature and leave no decomposition products, allowing lowtemperature calcination and high reactivity for the final oxides. ${ }^{6)}$

To obtain high-density GDC at low temperatures, there is a method of using transition metal oxides of $\mathrm{Co}, \mathrm{Mn}, \mathrm{Fe}$, etc. as a sintering aid, in addition to the synthesis of powders with excellent sinterability. ${ }^{10-13)}$ Among these oxides, Co oxides are known to lower the sintering temperatures most effectively and to enable sintering at $850^{\circ} \mathrm{C} \sim 1000^{\circ} \mathrm{C}$. How-

${ }^{\dagger}$ Corresponding author : Soo-Man Sim

E-mail : smsim@hongik.ac.kr

Tel : +82-44-860-2518 Fax : +82-44-862-2774 ever, no studies have been attempted on preparation of GDC by the addition of sintering aids to submicron-size commercial powders, while most results of the studies on preparation of GDC by using sintering aids were obtained from nano-powders and powders synthesized by the solution method. In the present study, we have synthesized GDC20 $\left(\mathrm{Ce}_{0.8} \mathrm{Gd}_{0.2} \mathrm{O}_{1.9}\right)$ powder from the slurry of a mixture of submicron-sized $\mathrm{CeO}_{2}$ powder and Gd precipitates precipitated by ammonium carbonate $\left(\left(\mathrm{NH}_{4}\right)_{2} \mathrm{CO}_{3}\right)$; and investigated its thermal decomposition and phase-forming behavior, calcination behavior and the effect of $5 \mathrm{~mol} \% \mathrm{CoO}$ doping on sintering.

\section{Experimental Procedure}

$\mathrm{CeO}_{2}$ powder (99.99\%, Kojundo Chem.), 0.5M Gd nitrate $\left(\mathrm{Gd}\left(\mathrm{NO}_{3}\right)_{3} \cdot 6 \mathrm{H}_{2} \mathrm{O}, 99.9 \%\right.$, Sigma-Aldrich) solution, and $1 \mathrm{M}$ ammonium carbonate $\left(\left(\mathrm{NH}_{4}\right)_{2} \mathrm{CO}_{3}\right.$, Sigma-Aldrich) solution as a precipitant were used for the synthesis of GDC20 powder.

A slurry was prepared by slowly injecting Gd nitrate solution into an attrition jar containing $\mathrm{CeO}_{2}$ powder and $\mathrm{ZrO}_{2}$ balls $(\Phi 3 \mathrm{~mm})$ while being stirred at a low speed. The ammonium nitrate solution (2.5 times of the moles of $\mathrm{Gd}$ ) was slowly added into the jar. The jar was rotated at 500 rpm and the milling was continued until complete precipitation. The resulting slurry, a mixture of $\mathrm{CeO}_{2}$ powder and $\mathrm{Gd}$ precipitates, was filtered with a filter press (YT30 142HW, Millipore), and subjected to repeated washing with deionized water and ethanol, followed by drying at $80^{\circ} \mathrm{C}$ for $12 \mathrm{~h}$. Then the dried powder was calcined at $700^{\circ} \mathrm{C}$ for $4 \mathrm{~h}$ followed by ball-milling for $2 \mathrm{~h}$ using $\mathrm{ZrO}_{2}$ balls $(\Phi 10 \mathrm{~mm})$ and then allowed to dry naturally with continuous stirring. For $\mathrm{CoO}$ doping, the powder was mixed with Co nitrate 
$\left(\mathrm{Co}\left(\mathrm{NO}_{3}\right)_{2} \cdot 6 \mathrm{H}_{2} \mathrm{O},>98 \%\right.$, Aldrich), a sintering aid, in ethanol. Then the mixture was ball milled for $2 \mathrm{~h}$ with $\mathrm{ZrO}_{2}$ ball ( $\Phi 10 \mathrm{~mm})$, dried at room temperature, and calcined at $300^{\circ} \mathrm{C}$ in air for $4 \mathrm{~h}$. The amount of $\mathrm{CoO}$ corresponded to 5 $\mathrm{mol} \%$ of GDC20 $\left(\mathrm{Ce}_{0.8} \mathrm{Gd}_{0.2} \mathrm{O}_{1.9}\right)$.

The powder was mixed with a binder $(0.5 \mathrm{wt} \%$, PVB, Aldrich), uniaxially pressed into pellets $(\Phi 15 \mathrm{~mm})$ at 50 $\mathrm{MPa}$ and subsequently isostatically pressed at $200 \mathrm{MPa}$. The pellets were held at $600^{\circ} \mathrm{C}$ for $2 \mathrm{~h}$ to remove the binder and sintered at $1100^{\circ} \mathrm{C} \sim 1500^{\circ} \mathrm{C}$ in air for $4 \mathrm{~h}$.

Thermal decomposition behavior of GDC powder was investigated at a heating rate of $5^{\circ} \mathrm{C} / \mathrm{min}$ in air up to $1000^{\circ} \mathrm{C}$ by TG/DTA (TG-DTA 2000, MAC Science). For phase analysis, the powders were heated at $400^{\circ} \mathrm{C} \sim 1000^{\circ} \mathrm{C}$ in air for $2 \mathrm{~h}$ and examined by XRD ( $\mathrm{CuK}_{\alpha}, \mathrm{M} 03 \mathrm{XHF}, \mathrm{MAC}$ Science). The sintered samples were also analyzed. Specific surface area of the calcined powder was measured by the multi-point BET method (BELSORP-mini II, BEL Japan Inc.). The average equivalent particle size $\left(D_{B E T}, \mathrm{~nm}\right)$ was calculated using the following equation.

$$
D_{B E T}=\frac{6 \times 10^{3}}{d_{t h} \times S_{B E T}}
$$

where $d_{t h}$ represents the theoretical density of GDC20, and $S_{B E T}$ the specific surface area $\left(\mathrm{m}^{2} / \mathrm{g}\right)$. Bulk density of the sintered sample was determined according to the Archimedes principle. Relative density was calculated from the theoretical density of GDC $\left(7.22 \mathrm{~g} / \mathrm{cm}^{3}\right)^{3)}$ and the bulk density. Particle size distribution was measured with a laser diffraction particle size analyzer (SALD-2001, Shimadzu). The morphology of the powder and microstructures of the sintered samples were observed with a SEM (FE-SEM, FEI).

\section{Results and Discussion}

Figure 1(a) shows a TG/DTA curve of Gd precipitates obtained under the same conditions of GDC powder synthesis. The $\mathrm{Gd}$ precipitate is presumably a basic carbonate of $\mathrm{Gd}\left(\mathrm{Gd}(\mathrm{OH}) \mathrm{CO}_{3} 2.5 \mathrm{H}_{2} \mathrm{O}\right)$ which is known to form at 2.5 molar ratio of $\left(\mathrm{NH}_{4}\right)_{2} \mathrm{CO}_{3}$ to $\mathrm{Gd}^{3+}$ ions. ${ }^{6)}$ The endothermic peak at $\sim 100^{\circ} \mathrm{C}$ accompanied by a weight loss was due to evaporation of the adsorbed water, while the weight loss up to $\sim 650^{\circ} \mathrm{C}$ was caused by removal of the crystal water and decomposition of the carbonate. The total weight loss was found to be $39.7 \%$. Fig. 1(b) shows a TG/DTA curve of the mixture of $\mathrm{CeO}_{2}$ powder and $\mathrm{Gd}$ precipitates; only thermal decomposition behavior of the $\mathrm{Gd}$ precipitates was observed because $\mathrm{CeO}_{2}$ powder was present along with the precipitates. The precipitates showed a gradual weight loss up to $\sim 650^{\circ} \mathrm{C}$ without any endothermic peak unlike in Fig. 1(a). Since $\mathrm{CeO}_{2}$ is mostly present in the precipitate, the weight loss due to decomposition of $\mathrm{Gd}$ precipitates was only $15.6 \%$, and all of the precipitates were changed to $\mathrm{Gd}_{2} \mathrm{O}_{3}$ at $\sim 650^{\circ} \mathrm{C}$ with almost no weight change.

Figure 2 shows XRD patterns of the GDC powders calcined for $2 \mathrm{~h}$. The as-prepared powder exhibited only $\mathrm{CeO}_{2}$
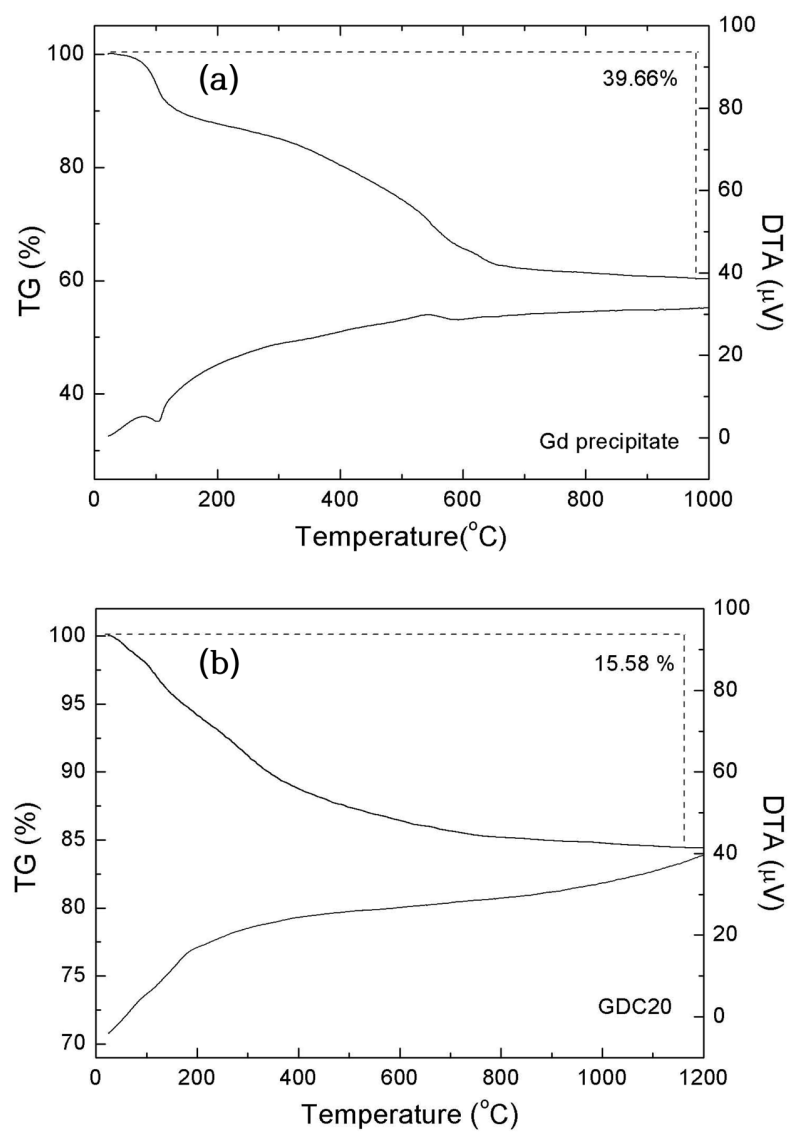

Fig. 1. TG/DTA curves of as-prepared powders at a heating rate of $5^{\circ} \mathrm{C} / \mathrm{min}$ in air: (a) $\mathrm{Gd}$ precipitate and (b) GDC precipitate.

diffraction peaks of the fluorite structure since the Gd precipitates were in the form of amorphous carbonate. The intensities of diffraction peaks were greatly increased at $1000^{\circ} \mathrm{C}$ as the crystal growth was accelerated with increasing the calcination temperature. Also, only $\mathrm{CeO}_{2}$ diffraction peaks were observed at all calcination temperatures because main $\mathrm{Gd}_{2} \mathrm{O}_{3}$ peaks overlapped with $\mathrm{CeO}_{2}$ peaks and a small amount of $\mathrm{Gd}_{2} \mathrm{O}_{3}$ contained in the sample.

Figure 3 shows XRD patterns of the samples doped with 0 and $5 \mathrm{~mol} \%$ of $\mathrm{CoO}$ and sintered at $1400^{\circ} \mathrm{C}$ for $4 \mathrm{~h}$. Both samples revealed $\mathrm{CeO}_{2}$ diffraction peaks of higher intensity than those calcined at $1000^{\circ} \mathrm{C}$. In the doped sample, there was no diffraction peaks due to Co oxide observed. The diffraction peaks of the sintered samples are considered to correspond to GDC. $\mathrm{CeO}_{2}$ solid solution can form during the calcination process because of high reactivity of decomposed nano-crystalline $\mathrm{Gd}_{2} \mathrm{O}_{3}$ particles. It has been reported that a mixture of $\mathrm{Ce}$ and $\mathrm{Gd}$ oxides forms a solid solution at temperature above $1500^{\circ} \mathrm{C}$, while co-precipitate of $\mathrm{Ce}$ and $\mathrm{Gd}$ forms a solid solution at relatively low calcination temperature. $^{14)}$

Table 1 shows specific surface areas and particle diameters $\left(\mathrm{D}_{\mathrm{BET}}\right)$ of the GDC powder calcined at various tempera- 


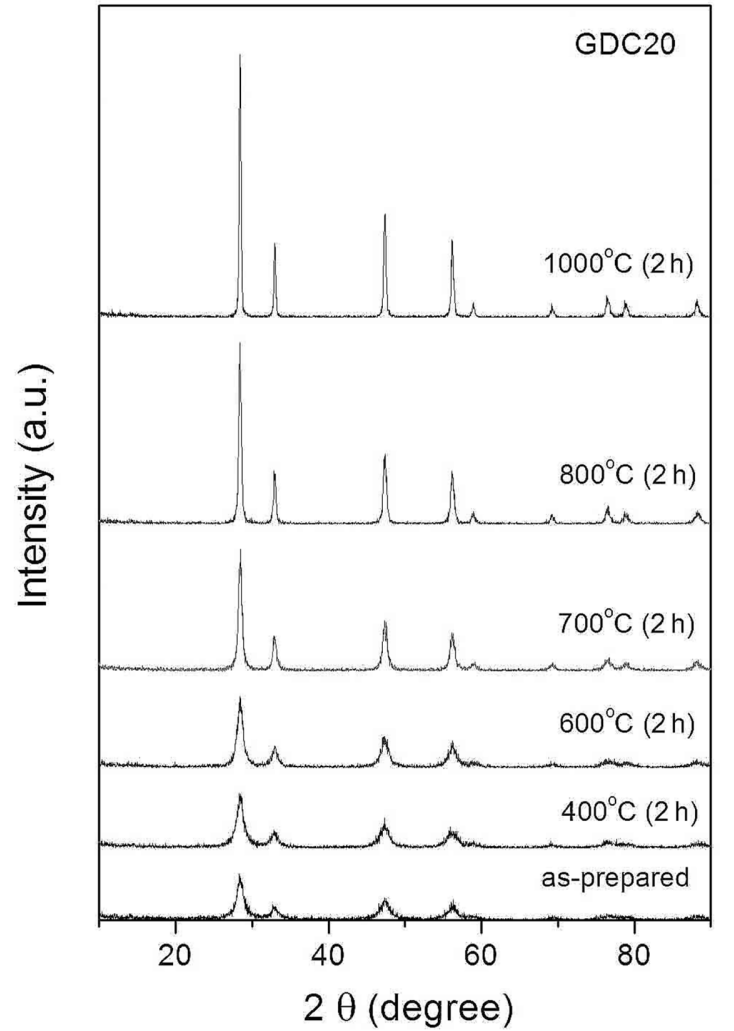

Fig. 2. XRD patterns of as-prepared GDC powders calcined at various temperatures.

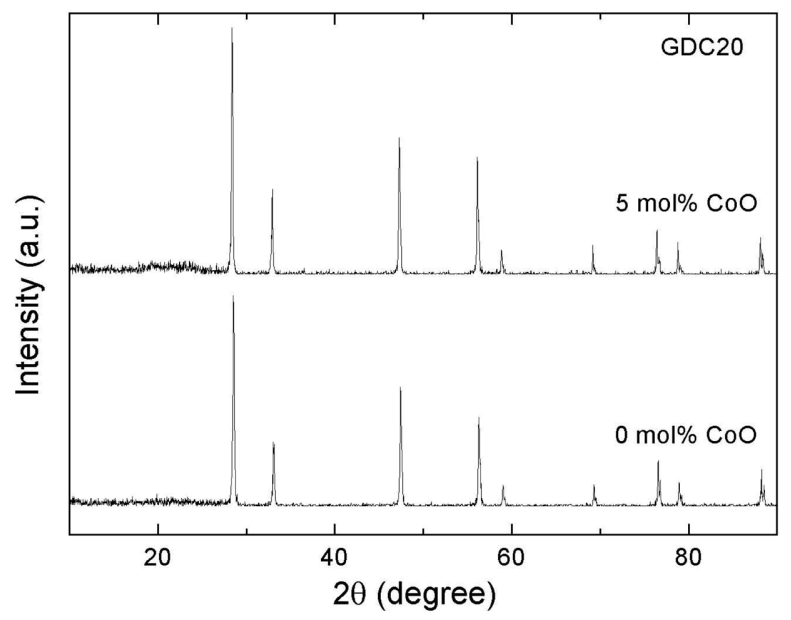

Fig. 3. XRD patterns of GDC samples doped with 0 and 5 $\mathrm{mol} \% \mathrm{CoO}$ sintered at $1400^{\circ} \mathrm{C}$ for $4 \mathrm{~h}$.

Table 1. Surface Areas and Particle Sizes of GDC Powders Calcined at Various Temperatures

\begin{tabular}{cccc}
\hline $\begin{array}{c}\text { Temperature } \\
\left({ }^{\circ} \mathrm{C}\right)\end{array}$ & Time (h) & $\begin{array}{c}\text { Specific surface } \\
\text { area }\left(\mathrm{m}^{2} / \mathrm{g}\right)\end{array}$ & $\begin{array}{c}\text { Calculated } \\
\mathrm{D}_{\text {BET }}(\mathrm{nm})\end{array}$ \\
\hline 400 & 2 & 97.6 & 8.5 \\
600 & 2 & 76.6 & 10.8 \\
& 4 & 76.3 & 10.9 \\
700 & 2 & 38.1 & 21.8 \\
& 4 & 37.0 & 22.5 \\
800 & 2 & 19.4 & 42.9 \\
1000 & 2 & 7.5 & 110.6 \\
\hline
\end{tabular}
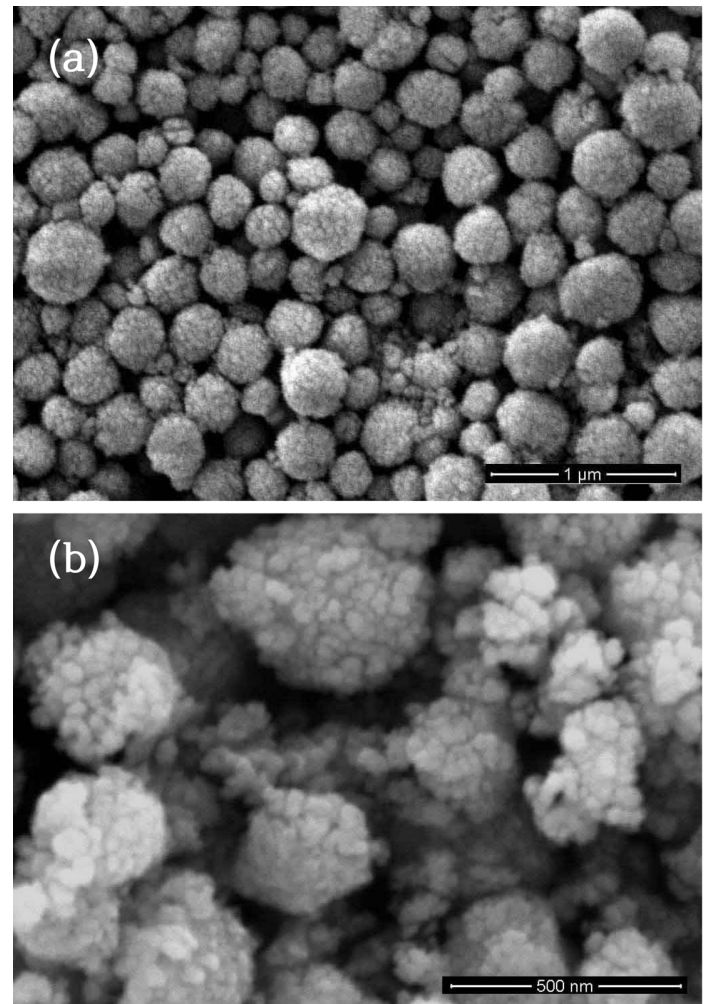

Fig. 4. SEM micrographs of (a) as-received $\mathrm{CeO}_{2}$ and (b) calcined GDC powders.

tures. The specific surface area of the powder was drastically decreased from $97.6 \mathrm{~m}^{2} / \mathrm{g}$ to $7.5 \mathrm{~m}^{2} / \mathrm{g}$ due to particle growth as the calcination temperature was increased from $400^{\circ} \mathrm{C}$ to $1000^{\circ} \mathrm{C}$. Since the particle growth was slow at $600^{\circ} \mathrm{C}$ and $700^{\circ} \mathrm{C}$ even after calcination up to $4 \mathrm{~h}$ the specific surface areas of the powders calcined for $4 \mathrm{~h}$ showed little difference from those calcined for $2 \mathrm{~h}$. The calculated BET particle size based on spherical and nonporous particles represents primary particle size. The primary particle size increased from $8.5 \mathrm{~nm}$ to $21.8 \mathrm{~nm}$ when the temperature was changed from $400^{\circ} \mathrm{C}$ to $700^{\circ} \mathrm{C}$, and the particle size increased greatly to $110.6 \mathrm{~nm}$ at $1000^{\circ} \mathrm{C}$ because of the acceleration in particle growth above $800^{\circ} \mathrm{C}$. Such particle growth can also be seen from the large increase in the intensity of diffraction peaks at temperatures above $700^{\circ} \mathrm{C}$ as shown in Fig. 2.

Figures 4 (a) and (b) are SEM photographs of $\mathrm{CeO}_{2}$ powder and calcined GDC powder, respectively, showing almost similar particle sizes and shapes. $\mathrm{CeO}_{2}$ powder of Fig. 4(a) consists of spherical particles with an average particle size of $0.46 \mu \mathrm{m}$ where nano-sized primary particles are agglomerated. In GDC powder of Fig. 4(b), the primary particles were grown to the size similar to the BET particle size (22.5 $\mathrm{nm}$ ) in the calcination process, and severely agglomerated. According to the particle size distribution in Fig. 5, the calcined powder had an average particle size of $0.47 \mu \mathrm{m}$ with a distribution from $0.3 \mu \mathrm{m}$ to $1 \mu \mathrm{m}$ in particle sizes, showing a 


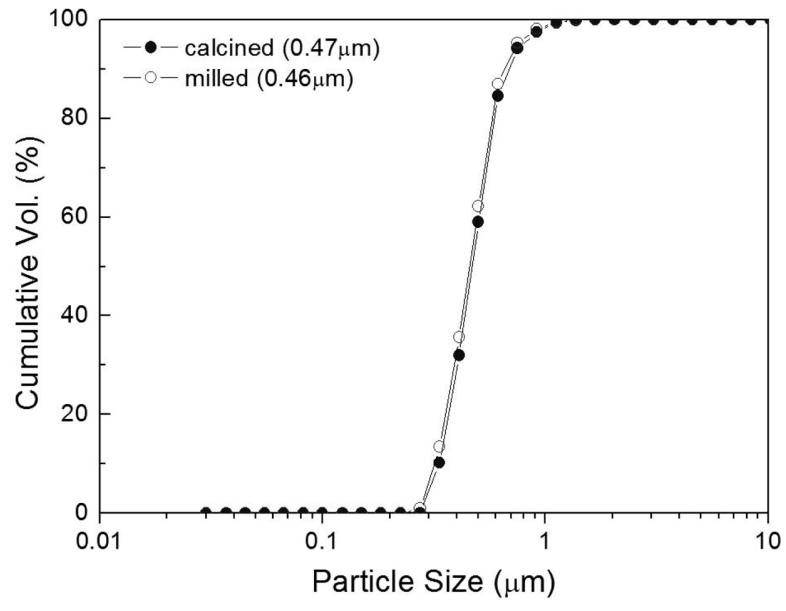

Fig. 5. Particle size distributions of calcined and milled GDC powders.

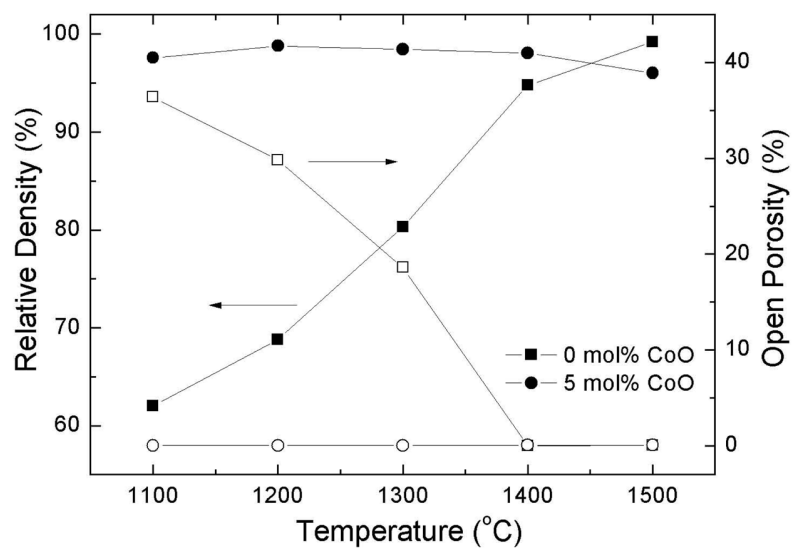

Fig. 6. Relative densities and open porosities of GDC samples doped with 0 and $5 \mathrm{~mol} \% \mathrm{CoO}$ sintered at various temperatures for $4 \mathrm{~h}$.

very uniform distribution. When the calcined powder was ball-milled for $2 \mathrm{~h}$, the powder showed a slight reduction in average particle size to $0.46 \mu \mathrm{m}$ but the same particle size distribution as that of the calcined powder.

Figure 6 shows relative densities and open porosities of the GDC samples sintered at $1100^{\circ} \mathrm{C} \sim 1500^{\circ} \mathrm{C}$ for $4 \mathrm{~h}$. Since partial sintering occurred in the pure GDC samples at $1100^{\circ} \mathrm{C}$, the density was only $62.0 \%$. After a gradual increase due to slow densification between $1100^{\circ} \mathrm{C}$ and $1400^{\circ} \mathrm{C}$, the density became $99.2 \%$ at $1500^{\circ} \mathrm{C}$. Sinterability of the GDC powder prepared in the present study was found to be excellent as compared with that from the mixed oxide method. The density of GDC20 prepared from $\mathrm{CeO}_{2}$ and $\mathrm{Gd}_{2} \mathrm{O}_{3}$ powders of $0.5 \mu \mathrm{m}$ in particle size by Ma et al. ${ }^{14)}$ was $73 \%$ at $1300^{\circ} \mathrm{C}$, which was lower than $80.3 \%$ in the present study, and became $97 \%$ at $1600^{\circ} \mathrm{C}$. Although Torrens et al. ${ }^{15)}$ also reported the density of $98 \%$ at $1650^{\circ} \mathrm{C}$ with the GDC20 powder of $0.3 \mu \mathrm{m}$ in particle size, the density at $1400^{\circ} \mathrm{C}$ was only $86 \%$, which was considerably lower than that found in the present study (94.8\%).
For the GDC powder doped with $5 \mathrm{~mol} \% \mathrm{CoO}$, densification was completed at $1100^{\circ} \mathrm{C}$ because of the excellent sinterability, a density of $97.6 \%$ was already achieved, and a density of $98.8 \%$, which was similar to the density of the pure $\mathrm{GDC}$ at $1500^{\circ} \mathrm{C}(99.2 \%)$, was obtained only at $1200^{\circ} \mathrm{C}$. However, at temperatures above $1300^{\circ} \mathrm{C}$, a tendency of gradual decrease in density was exhibited. Open pores in the doped samples completely disappeared at $1100^{\circ} \mathrm{C}$, whereas the open pores in the pure GDC samples disappeared at $1400^{\circ} \mathrm{C}$. This indicates that $\mathrm{CoO}$ doping enhances densification. Even though the present study did not reach the results for doping nano-powder with $\mathrm{CoO}$, the study suggests that preparation of dense GDC at low temperatures is possible by using submicron-sized $\mathrm{CeO}_{2}$ powder. Kleinlogel and Gauckler ${ }^{10)}$ obtained a density higher than $99 \%$ at $900^{\circ} \mathrm{C}$ by doping GDC20 nano-powder with $5 \mathrm{~mol} \%$ $\mathrm{CoO}$, while Nicholas and De Jonghe ${ }^{12)}$ also reported the density of $93.3 \%$ at $800^{\circ} \mathrm{C}$ by doping $\mathrm{GDC} 10\left(\mathrm{Ce}_{0.9} \mathrm{Gd}_{0.1} \mathrm{O}_{1.95}\right)$ nano-powder with $5 \mathrm{~mol} \% \mathrm{CoO}$. Recently, Hari Prasad et al. ${ }^{13)}$ have obtained the density of $97 \%$ at $850^{\circ} \mathrm{C}$ through doping GDC10 powder prepared by hydrate precipitation method with $3 \mathrm{~mol} \%$ Co.

Figures 7 (a), (b), and (c) are SEM photographs of the pure GDC samples sintered at $1100^{\circ} \mathrm{C}, 1300^{\circ} \mathrm{C}$ and $1500^{\circ} \mathrm{C}$, respectively. In the pure $\mathrm{GDC}$, no sintering occurred at $1100^{\circ} \mathrm{C}$ (Fig. 7(a)), and grains began to form by particle coalescence and many pores of irregular forms were present between particles at $1300^{\circ} \mathrm{C}$ (Fig. 7(b)). At $1500^{\circ} \mathrm{C}$, however, densification was completed, resulting in pore-free microstructure as shown in Fig. 7(c). Large pores of irregular forms disappeared completely and grains were grown up to $\sim 5 \mu \mathrm{m}$ in size.

Figures 8 (a), (b), and (c) are SEM photographs of the samples doped with $5 \mathrm{~mol} \% \mathrm{CoO}$ and sintered at $1100^{\circ} \mathrm{C}, 1300^{\circ} \mathrm{C}$ and $1500^{\circ} \mathrm{C}$, respectively, illustrating the effect of $\mathrm{CoO}$ doping on GDC sintering. In the doped samples, densification was nearly completed at $1100^{\circ} \mathrm{C}$, reaching the density of $97.6 \%$ with well-developed grains of $\sim 0.5 \mu \mathrm{m}$ in size, and the density reached $98.5 \%$ at $1300^{\circ} \mathrm{C}$ with grains grown to a size of $\sim 3 \mu \mathrm{m}$. Although the density was rather decreased when the sintering temperature was raised to $1500^{\circ} \mathrm{C}$, grain growth was accelerated so much that the grains were significantly increased to $\sim 20 \mu \mathrm{m}$ in size.

Many reports have shown that the addition of cobalt oxides enhances sintering of GDC due to liquid phase formed with impurities or increased grain boundary mobility by dissolution of Co in GDC. ${ }^{10-13)}$ However, it could not be ascertained by the present results. The reduction of densities with increasing the sintering temperatures can be attributed to the pores at $1500^{\circ} \mathrm{C}$ which were not visible at $1100^{\circ} \mathrm{C}$ as shown in Fig. 8(a)). These were presumably produced by volatilization of $\mathrm{CoO}$, which is known to have a very high volatility above $1400^{\circ} \mathrm{C} .^{14)}$ 

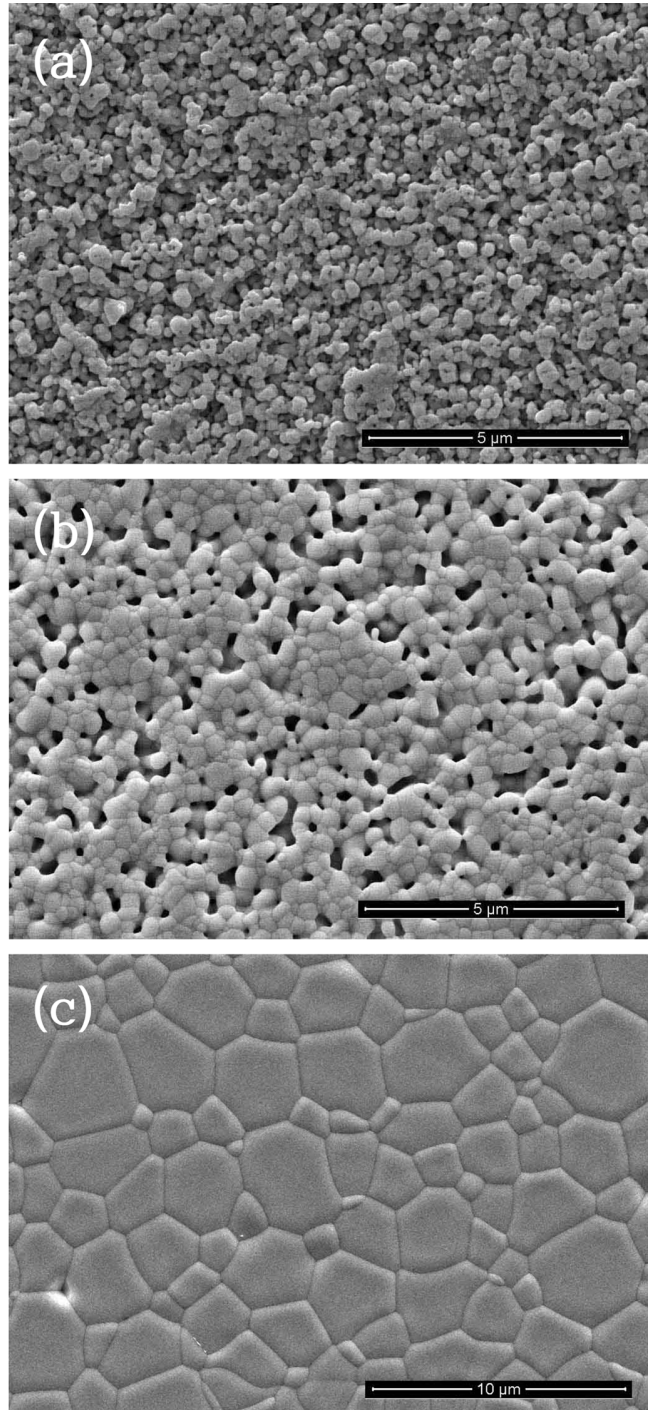

Fig. 7. SEM micrographs of undoped GDC samples sintered at (a) $1100^{\circ} \mathrm{C}$, (b) $1300^{\circ} \mathrm{C}$, and (c) $1500^{\circ} \mathrm{C}$

\section{Conclusions}

Mixtures of submicron-sized $\mathrm{CeO}_{2}$ powder and $\mathrm{Gd}$ precipitates were calcined at $700^{\circ} \mathrm{C}$ for $4 \mathrm{~h}$ followed by ball-milling that resulted in GDC20 powder with an average particle size of $0.46 \mu \mathrm{m}$. The powder consisting of spherical particles had a very uniform particle size distribution with particle sizes ranging from $0.3 \mu \mathrm{m}$ to $1 \mu \mathrm{m}$. GDC sample doped with $5 \mathrm{~mol} \% \mathrm{CoO}$ exhibited an excellent sinterability allowing a density as high as $97.6 \%$ at $1100^{\circ} \mathrm{C}$. The density of $98.8 \%$ was obtained only at $1200^{\circ} \mathrm{C}$, which was lower by as much as $300^{\circ} \mathrm{C}$ from $1500^{\circ} \mathrm{C}$ at which pure GDC has the density of $99.2 \%$. The doped GDC grains $\left(\sim 0.5 \mu \mathrm{m}\right.$ in size at $\left.1100^{\circ} \mathrm{C}\right)$ were grown to $\sim 20 \mu \mathrm{m}$ at $1500^{\circ} \mathrm{C}$ due to the enhanced grain growth by $\mathrm{CoO}$ doping, whereas the grains of pure GDC grew to only $\sim 5 \mu \mathrm{m}$ at $1500^{\circ} \mathrm{C}$.
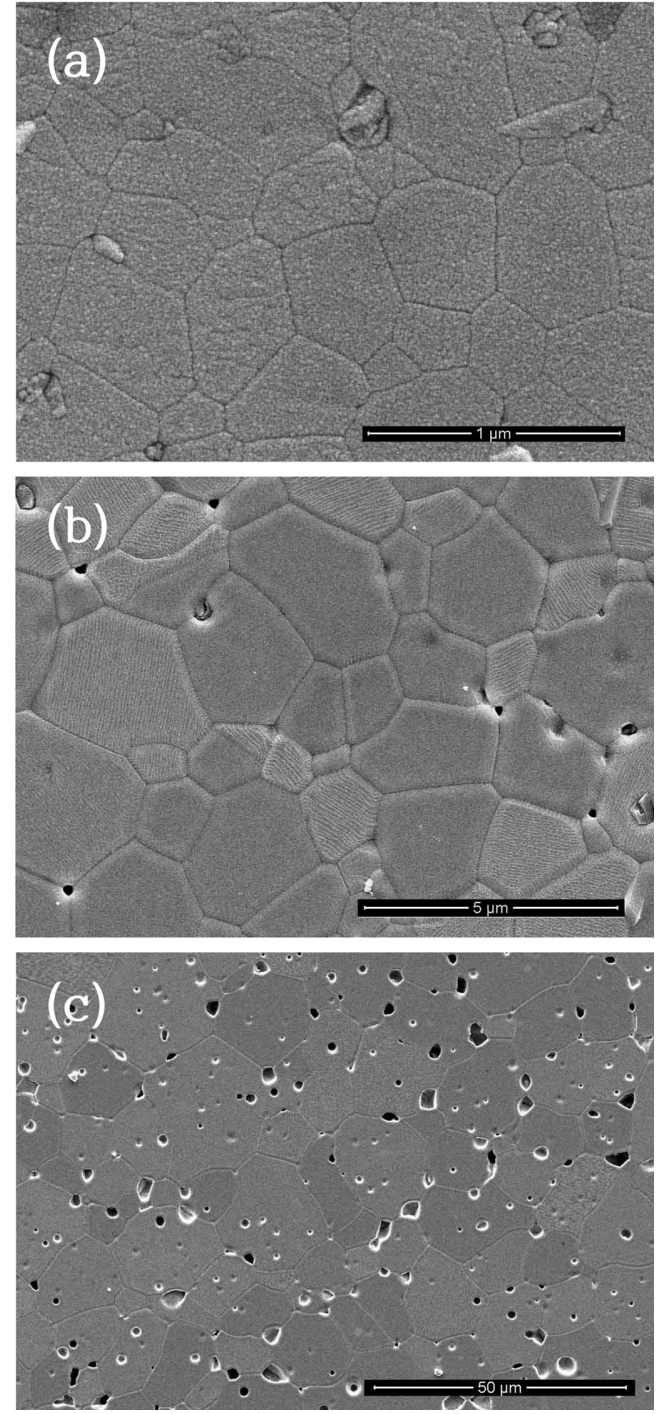

Fig. 8. SEM micrographs of GDC samples doped with $5 \mathrm{~mol} \%$ $\mathrm{CoO}$ sintered at (a) $1100^{\circ} \mathrm{C}$, (b) $1300^{\circ} \mathrm{C}$, and (c) $1500^{\circ} \mathrm{C}$.

\section{REFERENCES}

1. H. Inaba and H. Tagawa, "Review Ceria-Based Solid Electrolytes," Solid Sate Ionics, 83 1-16 (1996).

2. K. Higashi, K. Sonoda, H. Ono, S. Sameshima, and Y. Horata, "Synthesis and Sintering of Rare-Earth-Doped Ceria Powder by Oxalate Coprecipitation Method," J. Mater. Res., 14 [3] 957-67 (1999).

3. I.-D. Han, K.-Y. Lim, and S.-M. Sim, "Preparation and Sintering Characteristics of Gd-doped $\mathrm{CeO}_{2}$ Powder by Oxalate Co-Precipitation," J. Korean Ceram. Soc., 43 [10] 66672 (2006).

4. D. Hair Prasad, H.-R. Kim, J.-S. Park, J.-W. Son, B.-K. Kim, H.-W. Lee, and J.-H. Lee, "Superior Sinterability of Nono-Crystalline Gadolinium Doped Ceria Powders Synthesized by Co-Precipitation Method," J. Alloys Compd., 495 238-41 (2010).

5. J.-G. Li, T. Ikegami, Y. Wang, and T. Mori, "10 mol\% 
$\mathrm{Gd}_{2} \mathrm{O}_{3}$-Doped $\mathrm{CeO}_{2}$ Solid Solutions via Carbonate Coprecipitation: A Compartive Study,” J. Am. Ceram. Soc., 86 [6] 915-21 (2003).

6. A. I. Y. Tok, L. H. Luo, and F. Y. C. Boey, "Carbonate Coprecipitation of $\mathrm{Gd}_{2} \mathrm{O}_{3}$-doped $\mathrm{CeO}_{2}$ Solid Solution NanoParticles," Mat. Sci. \& Eng., A383 229-34 (2004).

7. Y.-C. Yoo, B.-J. Chung, and S.-M. Sim, "Preparation and Sintering Characteristics of $\mathrm{Ce}_{0.8} \mathrm{Gd}_{0.2} \mathrm{O}_{1.9}$ Powder by Ammonium Carbonate Co-Precipitation," J. Korean Ceram. Soc., 49 [1] 118-23 (2012).

8. R. O. Fuentes and R. T. Baker, "Structural, Morphological and Electrical Properties of $\mathrm{Gd}_{0.1} \mathrm{Ce}_{0.9} \mathrm{O}_{1.95}$ Prepared by a Citrate Complexation Method," J. Power Sources, 186 26877 (2009)

9. L. D. Jadhav, M. G. Chourashiya, K. M. Subhedar, A. K. Tyagi, and J. Y. Patil, "Synthesis of Nanocrystalline Gd Doped Ceria by Combustion Technique," J. Alloys Compd., 470 383-86 (2009).

10. C. M. Kleinlogel and L. J. Gauckler, "Sintering and Properties of Nanosized Ceria Solid Solutions," Solid State Ionics, 135 567-73 (2000).
11. G. S. Lewis, A. Atkinson, B. C. H. Steele, and J. Drennan, "Effect of Co Addition on the Lattice Parameter, Electrical Conductivity and Sintering of Gadolinia-doped Ceria," Solid State Ionics, 152-153 567-73 (2002).

12. J. D. Nicholas and L. C. De Jonghe, "Prediction and Evaluation of Sintering Aids for Cerium Gadolinium Oxide," Solid State Ionics, 178 1187-94 (2007).

13. D. Hari Prasad, S. Y. Park, H. Ji, H.-R. Kim, J.-W. Son, B.K. Kim, H.-W. Lee, and J.-H. Lee, "Cobalt Oxide Co-doping Effect on the Sinterability and Electrical Conductivity of Nano-Crystalline Gd-Doped Ceria," Ceram. Int., 38S S497S500 (2012).

14. J. Ma, T. S. Zhang, L. B. Kong, P. Hing, and S. H. Chan, " $\mathrm{Ce}_{0.8} \mathrm{Gd}_{0.2} \mathrm{O}_{2.8}$ Ceramics Derived from Commercial Submicron-Sized $\mathrm{CeO}_{2}$ and $\mathrm{Gd}_{2} \mathrm{O}_{3}$ Powders for Use as Electrolytes in Solid Oxide Fuel Cells," J. Power Sources, 132 71-76 (2004).

15. R. S. Torrens, N. M. Sammes, and G. A. Tomsett, "Characterisation of $\left(\mathrm{CeO}_{2}\right)_{0.8}\left(\mathrm{GdO}_{1.5}\right)_{0.2}$ Synthesised Using Various Techniques," Solid State Ionics, 111 9-15 (1998). 